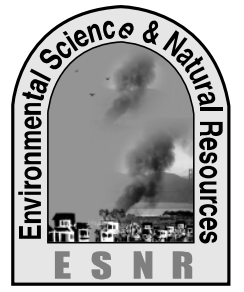

\title{
State of the Environment in Slum Area: A Case Study on Khora Slum, Khulna
}

\author{
T. T. Tanni ${ }^{1}$, M. J. Hasan ${ }^{1 *}$, A.K. Azad ${ }^{1}$ and B. Bakali ${ }^{2}$ \\ ${ }^{1}$ Environmental Science Discipline, Khulna University, Khulna, Bangladesh \\ ${ }^{2}$ Department of Environmental Science and Resource Management, \\ Mawlana Bhashani Science and Technology University, Tangail, Bangladesh
}

\begin{abstract}
The people fall in low income group is generally migrants and the local poor. Majority of slum people are living in poor quality housing where the absence of basic services and facilities is significant. The aim of the study is to evaluate the existing housing condition, to identify the present condition of sanitary facilities \& drainage facilities, to evaluate the present condition of drinking water quality (lab analysis) \& to determine the level of noise as this area is near to the main bus station $\&$ health services. To collect the required information random sampling method was used and questionnaire survey was done with slum dwellers. Lab analysis was made to find out the water quality. The noise level was measured using Noise Level meter. The study has tried to analyze the problem and advantages for living in the slum settlements, the slum settlements consequences on surroundings with a special reference of Khora Slum of Khulna City Corporation. The housing condition of the study area is not good. About $80 \%$ houses are in such a condition that it is very hard to live in there. The main problem is that these people are not aware of the environment where they are living as it is not their permanent living place. It was found that responsible authorities are not doing anything for the slum people. There is no qualified doctor in that area. Though the sadar hospital is nearer but they don't have enough money to go there. Mosquito is main problem here as there is no fixed place for throwing their household waste. Sanitation facilities are very poor here. There is only one community sanitary latrine with three chambers but it is not sufficient for all the people of the slum. Drinking water is another problem here as there exists only five tube wells of three are used by most of the people and the quality of water of the tube wells were analyzed in the lab. It was found that salinity level is very high $(10 \mathrm{ppt}) \&$ color is dark of the water of the tube wells. By this study it will be easy to get the idea about house rent structure of the slums, getting services and facilities of the slums, distance of the services and facilities from the settlements, water supply and other utility services conditions of the slums.
\end{abstract}

Key Words: Environment, Slum, Khulna, Housing, Sanitation, Water Quality.

\section{Introduction}

Slum is an unhealthy area where basic amenities like water supply, drainage for standard living are lacking, unsanitary conditions prevail and diseases flourish. Slums have legal owner of its land. The ownership may be public, organizational or private. Squatter settlements contain the same unhygienic condition like slums having no legal owner of its land. Rapid urbanization and inadequate capability of the respective authority to manage with the housing needs of people in urban areas have contributed to the development of informal settlements. Living in these settlements often poses significant health risks. The sanitation and drinking water quality of the informal settlements are often poor. About 30 percent (9 million) of them are living under poverty level and about 17 percent (5 million) are living in slum areas (World Bank Memorandum 1985, p: 35). According to the definition of urban poor by World Bank there are 12.45 million urban poor and 6.97 million urban hard-core poor in Bangladesh, who lived in slum and squatter settlements (Islam, 1998, p: 2) or in informal settlements. Khulna is the largest city in the south region and also the third largest Metropolitan city of Bangladesh. It is an industrial city. There are a large number of laborers in the city area. Mainly, they are living in the informal settlements. This is one of the reasons which are responsible for the growth of the informal settlements. Slum settlements which is directly treated as the informal settlements are about 202 in the Khulna City Corporation area (BBS, Census of slum and floating population, Vol:1, $P: X I I I)$. There is several interacting factors contribute to the process of marginalization or impoverishment of the urban poor, those are: Anti-poor national policies; High fertility; Environmental deterioration; Natural disasters; Cultural and ethnic factors; Exploitative intermediation and International processes. Population growth exerting tremendous pressure on productive natural resources, over exerting of natural resources also get impact on the sustainable environment protection and also lessen their income scale. In this way the poor are improvised and they are depressed in taking any risk which can improved their income as well as their life style (IFAD 1992). Most of the area of Khulna city is unplanned and unauthorized, which are full of various problems like proper accessibility, lack of adequate services facilities, orientation and zoning problems. A vast majority of the population of Khulna is living below poverty level and most of them are occupied either in various informal sector jobs or small, 
medium and large sized industries as workers. As a result, they are compelled to live in slums and squatter areas without having least access to basic urban services and facilities. Urban poor are those who live in urban areas and unable to meet their basic needs with their own income. Maximum calorie intakes per day of them are 2122 cal. The World Bank identified two major groups: The 'Poor' that is those who earn less than Tk. 2600 per month for the average family group of six persons; and the 'hardcore Poor' who earn less Tk. 1724 per month (BCAS 1991). The people whose income is below Tk. 3500 monthly and generally who are living in semi-pucca and kutcha houses are denoted as the urban poor housing. On an average per year population is increasing at a rate of $4.13 \%$ (Firoz, 2004) in Khulna city. The major causes are natural growth and migration and generally migrated people take shelter in low income housing. For cause of low level of income people cannot afford better housing and this enhance the formation of low income housing. Slums are scattered almost everywhere of the city. Living in sub-standard condition and about $18 \%$ of people live in slums. Generally the low income people of different occupation (like rickshaw pullers, pull cost pullers, scooter drivers, petty shopkeepers, laborer) live in the slum houses. Abedin, "Our Cities and Towns", 1968, The author shows that the economic ones emphasize a house as a good investment, as an incentive to save, as a way of improving credit standing in the community, and as freedom from landlord. The social reasons, which encourage home ownership family, pride in owing, family security a brief in the virtue of private property ownership and a sense of better citizenship. But the author did not show how the housing unit would be available in the urban low income people. But the present study will try to identify the existing household condition particularly in the urban low income people and to propose in low cost housing in the study area. "Slum appears to be plan less or even anti-plan". They have argued that in an industrial city the working-men's houses are situated near the industrial belt of the city; it may also be situated near the CBD area. They have shown a theory relating the urban growth as well as the slum. They have also identified the characteristics and living environment of the slum. They were successful in identifying the probable locations of slums and their situations, but the spatial impulse of the slums was not taken into consideration (Pellai. Devdas., Desai. ed., "Slum and Urbanization", pp. 11-14).

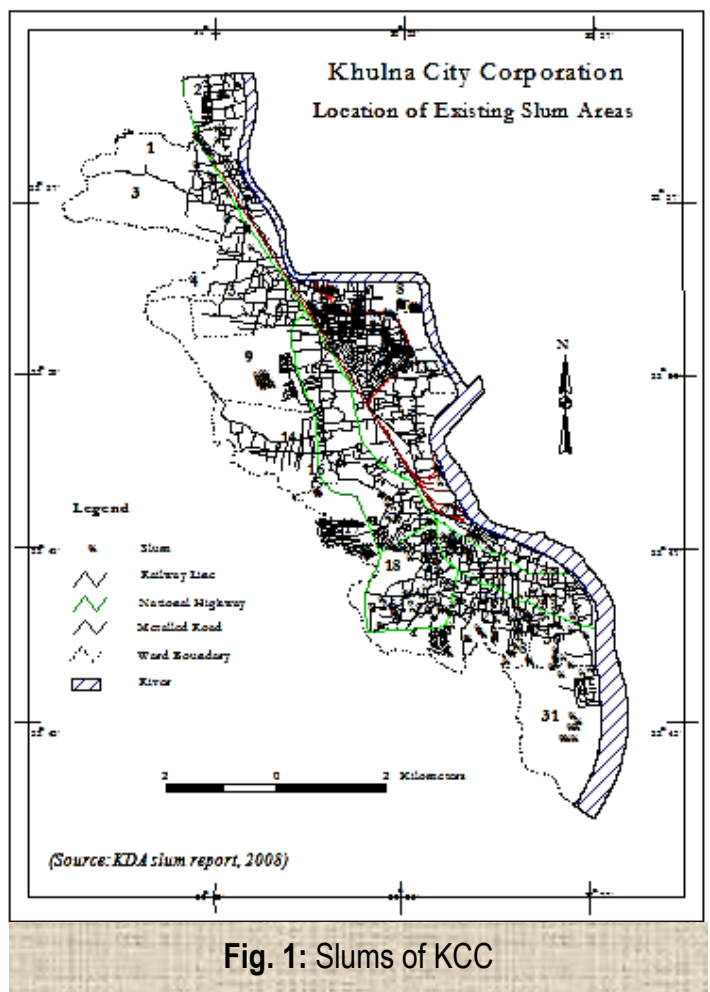

Materials \& Method: After setting the objectives of the study to reach the terminate point, a mental model was made that was the setting of thinking for achieving the goal of the study sequentially. The survey was conducted with the people of Khora Slum area. Quantitative data were collected from laboratory 
analysis \& the relevant organizations Local Government Engineering Department (LGED), KCC, BBS, Non-Govt. NGOs, Satellite image; digital map and different software (MS Word, MS Excel etc.) were utilized. All the collected data and information were compiled, analyzed and interpreted using different statistical formulae. In this study, the spatial analysis of the informal settlements, this is directly related to the informal settlements growth and is conducted with the locational view point of the informal settlement's location within the city, the reasons that the informal settlers live in a specific informal settlement. A large number of informal settlements have been observed in ward $17 \& 18$ in Khulna City Corporation area. Ward $17 \& 18$ is situated in most the important part of Khulna city. It is near about the Central Bus Terminal of Khulna city and is also near about the Boyra area. So, spatial analysis of informal settlements to this area is very important for the city. The Khora's Slum is the suitable area to conduct this type of study. Simple Random sampling method was used to collect information by questionnaire survey. To find out the drinking water quality various laboratory experiment were done. Samples were collected three times from the locations $\&$ by the same procedure. The water samples were collected from three different tube wells (TW1, TW2, TW3) at different locations of khora slum. The depth of the tube wells was $50 \mathrm{~m}, 46 \mathrm{~m}$, $48 \mathrm{~m}$ respectively. One-liter polyethylene bottles were acid washed for collecting water samples. Aeration during water sampling was avoided as far as possible. The water samples were carefully transported to the laboratory and preserved for chemical analysis. The following analysis have been done-Color \& Odor, $\mathrm{pH}$, EC (Electrical Conductivity) \&TDS (Total Dissolve Solids), Sodium $\left(\mathrm{Na}^{+}\right)$\& Potassium $\left(\mathrm{K}^{+}\right)$, Calcium $\left(\mathrm{Ca}^{2+}\right)$ and Magnesium $\left(\mathrm{Mg}^{2+}\right)$, Chloride $\left(\mathrm{Cl}^{-}\right)$, Carbonate $\left(\mathrm{CO}_{3}{ }^{2-}\right)$ \& Bicarbonate $\left(\mathrm{HCO}_{3}^{-}\right)$, Nitrate $\left(\mathrm{NO}_{3}{ }^{-}\right)$, Phosphate $\left(\mathrm{PO}_{4}{ }^{3-}\right)$, Sulphate $\left(\mathrm{SO}_{4}{ }^{2-}\right)$, Salinity, Fecal Coliform. Noise level was also recorded. For questionnaire survey Simple random sampling technique has been applied as sampling procedure. By the following equation the sample size was determined by Berensen and Levine, 1992. The study is based on both primary information (interview, questionnaire survey and oral talk with local persons and experts) and secondary information collected from various Government and non- government organization, published and unpublished documents. After processing, all data were analyzed and final report was prepared.

\section{Results:}

Educational Status of the Slum Dwellers: Educational status of the slum dwellers is not so high. Most of the people are illiterate. The percentage of illiterate people is $42.19 \%$ and the people who can sign only are $20.66 \%$. Some of them have primary level and a few have secondary level education. The percentages are 33.34 and 3.81 respectively. For high rate of illiterate, they are not aware enough about the necessity of education.

Occupational Status of the Slum Dwellers: Most of the people in the Khora's slum are illiterate. Male literacy rate is higher than the female. Most of the female are illiterate. Most of the literate people are in the primary level. Child literacy rate is better than the senior. In some cases, female do not go to the school and they stay in home. In some cases, people do not want to go their children in the school. Rather than they like to stay home to help their works. Most of the children read in government school and they need not spend any money for their reading. Most of the people in the slum area have to hard work to live. They work for all day long and after the day they have no time for the secondary occupation. For this reason, the income pattern of the slum is concentrated basically on primary occupation. Again most of the people in slum area are basically engaged with physical labor (83\%) rather than the mental labor. As their educational level is poor, so they can't get any job based on their educational qualification. For this reason they can never changes their life, moreover they have no willingness to improve their live standard sometime. But some of them have willingness to improve their life standard and they have done well, some of them are savings money from their income and invest them for earning more.

Income Distribution of the Slum Dwellers: As their educational level is poor, so they can't get any job based on the. For this reason they can never changes their life, moreover they have no willingness to improve their live standard sometime. But some of them have willingness to improve their life standard and they have done well, some of them are savings money from their income and invest them for earning more. Here most of the people are concentrated in 2000-3000Tk and 3000-4000Tk. Most of the people 
in the slum area have to hard work to live. They work for all day long and after the day they have no time for the secondary occupation.

\section{Condition of Housing and its Services \& Facilities:}

Khora slum is a small slum. There were one hundred and ninety three households in the slum 2 years ago. But now it is about 400-430 households. The maximum number of houses is thatched and tin-shed. Most of peoples are living here below the poverty line. So they have to effort low cost housing. About 60 percent houses are thatched here. The main part of housing materials is floor materials, wall materials and roof materials. The construction materials of pucca houses- floor materials are mainly brickcement, mosike, wall materials are brick cement and

Fig. 2. Materials of the buildings.

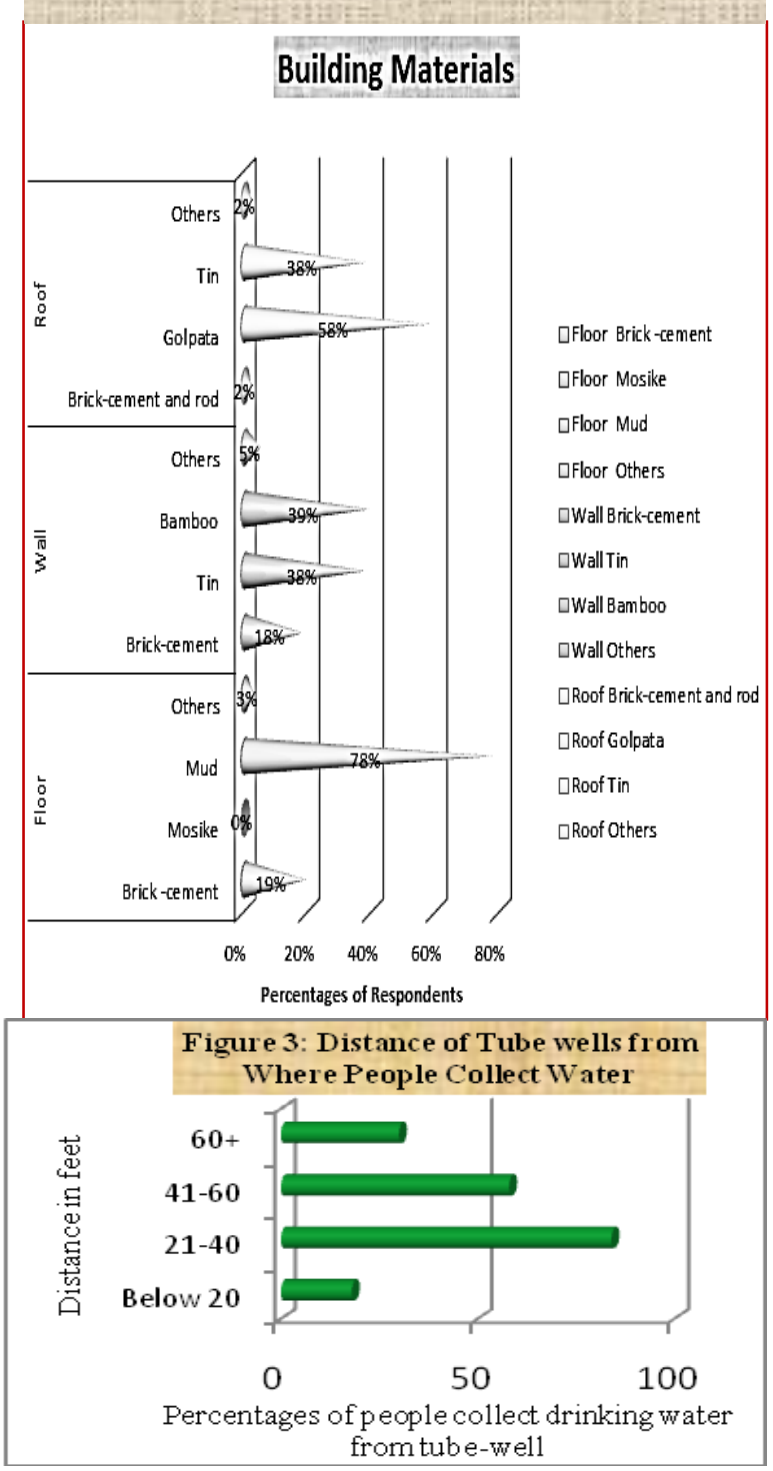

roof materials are brick cement with rod. The construction materials of semi pucca or partial pucca houses - floor materials are generally mud or only brick or brick cement, wall materials are brick cement and roof materials are tin, tail etc. And the construction materials of katcha houses (in this study all katcha houses are "jhupri" type low cost slum houses) are temporary houses- floors are made by mud, wall are made by mud, bamboo and roof are made by tin, Golpata. In this slum, the common materials of housing are Golpata, Tin, and Mud etc. The more detailed it can be exposed by the Figure 2.The people of the Khora's slum are not owner of the houses. They rent their houses. The size of houses are too small than any other better housing system. Because there are shortage of spaces but it have to occupy for a large population who are poor. So the houses of this are made of low cost housing materials and in a small space. For this reason a small number of rooms are consist of this houses. Most of the houses contain one room \& it is about $53 \%$ of the total households. So, it is very hard for them to adjust in one room as they have at least 4- 5 people in one family. The rent of houses are also too low than any other residential area of Khulna City. In this slum a house can be rented below 500 taka which is suitable for poor people live here. Thatched houses are most economically in here. Tin-shed, semi-pucca, pucca houses are more expensive than thatched respectively. The overall interior environment is not good in the slum area. It is the general scenario of the slum area that there has lack of space for air circulation and sunlight penetration. The household cleanliness is also in poor condition. The household members are not aware of their interior environment. Moreover the interior space is too congested that the area cannot properly maintain the interior furniture's. So, the haphazard situation is created.

Sources of Water in the Study Area: The sources of water for different purposes of the slum is mainly tube well and that of a minimum number. About $100 \%$ of the respondents said that they don't get any water supply from the KCC. Mainly they use tube well water for different purposes. Some of the use pond water for washing clothes, bathing etc. But for drinking water almost everyone collect water from tube wells $(96 \%)$. They have to walk for a certain distance to collect drinking water (Figure 3 ). 
Services of Water Supply and Sanitation: Water is used for not only drinking also for another purpose such as bathing, cooking, washing etc. This water is collected from pond, well, tube-well etc. In Khora's slum, there were seven tube wells to collect drinking water for daily life. But now there are only five tube wells (2 tube wells for personal use) to collect drinking water. Most of slum dwellers use the tubewells water for drinking, cooking or bathing. No tap water service is exists here. Slum dwellers collect their drinking water from tube-wells in different distance. It is clearly expressed that the need of establishing more deep tube-wells is high for fifty percent of slum dwellers. Because these tube-wells can cover only 108 household and 471 slum peoples (approximately).

Drinking Water Quality (lab analysis): To assess the suitability of potable water for drinking purposes hydro chemical parameters of drinking water were assessed out on different tube wells. The water quality parameters are discussed here comparing with standards of Bangladesh and World Health Organization (WHO) (Table 1).

Utility Service Facilities: Without water supply and sanitation services there are more utility services are needed to provide in a housing system such as electricity, open spaces, garbage disposal, access roads, drainage, health services etc. in khora's slum all utilities are not provided here but some are provided. The existing condition of utilities are providing in the Table 2 .

\begin{tabular}{l} 
Table 2. Utility Service Facilities (Source: survey, 2011) \\
\begin{tabular}{|c|c|c|c|}
\hline Name of Services & Yes (\%) & No (\%) & Remarks \\
\hline Electricity & 66 & 34 & $50 \%$ illegal \\
\hline Open space & Not Available & Not Available & \\
\hline Toilet & 76 & 24 & Without proper sanitation \\
\hline Garbage disposal & Not Available & Not Available & \\
\hline Access road & 81 & 19 & \\
\hline Drainage & Not Available & Not Available & \\
\hline Health & 90 & 10 & Not get service from a \\
& & & MBBS doctor \\
\hline
\end{tabular} \\
\hline
\end{tabular}

Sanitation Facilities: Sanitation is one of the most important services for any kind of housing. If sanitation is not hygienic then many types of diseases can assail to human beings. In Khora slum, the supplies of sanitation facilities are moderate. But these latrines are not sufficient for existing slum dwellers. There are only one community latrine with 5 chambers and covers almost $45 \%$ of the total household.

Mosquito Problem: Mosquito is big problem in a place like this slum. There is no initiatives yet taken to solve this particular problem. About $100 \%$ people said that this is a very big problem here and it causes many types of diseases

Table 1. Water Quality of tube wells (Source: Lab Analysis, 2011)

\begin{tabular}{|c|c|c|c|c|c|c|c|}
\hline $\begin{array}{l}\text { Serial } \\
\text { No. }\end{array}$ & $\begin{array}{l}\text { Water quality } \\
\text { parameter }\end{array}$ & Unit & $\begin{array}{l}\text { Banglad } \\
\text { esh } \\
\text { standar } \\
\text { d }\end{array}$ & $\begin{array}{l}\text { WHO } \\
\text { standard }\end{array}$ & TWl & TW2 & TW3 \\
\hline 01 & $\mathrm{pH}$ & - & $6.5-8.5$ & - & 6.15 & 7.20 & 6.95 \\
\hline 02 & $\begin{array}{l}\text { EC (Electrical } \\
\text { Conductivity) }\end{array}$ & $\mu \mathrm{sicm}$ & - & - & 8.15 & 12.64 & 8.07 \\
\hline 03 & $\begin{array}{l}\text { TDS (Total } \\
\text { Dissolved } \\
\text { solids) }\end{array}$ & phm & 1000 & 1000 & 600 & 500 & 550 \\
\hline 04 & Sodium $\left(\mathrm{Na}^{-}\right)$ & $\mathrm{ppm}$ & 200 & 200 & 1186.046 & 251.163 & 141.86 \\
\hline 05 & Potassium $\left(\mathrm{K}^{-}\right)$ & $\mathrm{ppm}$ & 12 & - & 23 & 2.1 & 3.1 \\
\hline 06 & Calcium $\left(\mathrm{Ca}^{2-}\right)$ & $\mathrm{ppm}$ & 75 & $75-200$ & 65 & 67 & 64 \\
\hline 07 & $\begin{array}{l}\text { Magnesium } \\
\left(\mathrm{Mg}^{2-}\right)\end{array}$ & $\mathrm{ppm}$ & $30-35$ & $50-150$ & 33 & 34 & 32 \\
\hline 08 & Chloride (Cl) & $\mathrm{ppm}$ & $150-600$ & 250 & 1132.26 & 260.7 & 180.90 \\
\hline 09 & $\begin{array}{l}\text { Carbonate } \\
\left(\mathrm{CO}_{3}{ }^{2 \cdot}\right)\end{array}$ & $\mathrm{ppm}$ & - & - & absent & 120 & absent \\
\hline 10 & $\begin{array}{l}\text { Bicarbonate } \\
\left(\mathrm{HCO}_{3}{ }^{\circ}\right)\end{array}$ & $\mathrm{ppm}$ & - & - & 689.30 & absent & 481.90 \\
\hline 11 & $\begin{array}{l}\text { Phosphate } \\
\left(\mathrm{PO}_{4}{ }^{3}\right)\end{array}$ & $\mathrm{ppm}$ & 6 & - & 0.53 & 0.75 & 0.97 \\
\hline 12 & Sulphate $\left(\mathrm{SO}_{4}^{2-}\right.$ & $\mathrm{ppm}$ & 400 & 250 & 0.085 & 1.66 & 0.076 \\
\hline 13 & Nitrate $\left(\mathrm{NO}_{3}{ }^{2}\right)$ & $\mathrm{ppm}$ & 10 & 50 & 0.14 & 0.82 & 0.96 \\
\hline 14 & Salimity & pht & - & - & 10 & 6 & 4 \\
\hline 15 & Fecal Coliform & $\mathrm{N} / 100 \mathrm{ml}$ & 0 & 0 & $\begin{array}{l}(-) x e \\
(0)\end{array}$ & $\begin{array}{l}(-) x e \\
(0)\end{array}$ & $\begin{array}{l}(-) x e \\
(0)\end{array}$ \\
\hline 16 & Odor & & Odorless & & Bad & Bad & Bad \\
\hline 17 & Color & & - & - & Dark & $\begin{array}{l}\text { Light } \\
\text { Datk }\end{array}$ & $\begin{array}{l}\text { Light } \\
\text { Dark }\end{array}$ \\
\hline
\end{tabular}


Drainage Facilities: There are no proper drainage systems in the total area. Some people use the khal as draine and at the same time use the water of the khal for different purposes. But in other slum, there exist some draine. It is found that most of the respondents have the provision of katcha drain. In the slum all the respondents have katcha drain because there is no pucca drain around the slum. The katcha drain is within 5 meters from their houses. As most of the respondents living in the slum have katcha drain adjacent to their houses the environmental condition of the slum is not hygienic. They throw their all kind of waste here and there and thus cause many health problems.

Waste Disposal: It was found that the highest numbers of households throw their household waste here and there. The percentage of this category has been found $36 \%$ of the total households. $8 \%$ households of the informal settlements used the dustbin as the households waste dispose place. 6\% households dispose their waste by dumping in definite places, which is environmentally sound. Other large portion of households of the informal settlements $(15 \%)$ disposes their waste in any small water logged areas near their houses.

Noise Level: The slum in very nearer to the bus terminal and by the side of the main road. The slum has main roads in two sides. So, it's noisy most of the time. The noise level is measured by a Noise meter. The data were taken in various time of the day and the data were taken for two days from every distance. So, it was identified that noise level is high here (between $60 \mathrm{~dB}-79 \mathrm{~dB}) \&$ the recorded maximum noise level was $79 \mathrm{~dB}$

Health Facilities: There is a dispensary nearby the slum. Most of the people go there for medicine but there is not any MBBS or qualified doctor. The sadar hospital is about $400 \mathrm{~m}$ away but the expense is high and the doctors don't care them well. From the basic need, health is an important facility is very important for human both urban and rural area. Health facilities of Khulna city is not bad, there is one medical college hospital and other Govt. hospitals and private clinic which serves the total people of Khulna city. In the study area there are two health centers but most of the people go to the specific one which is less costly for them. The field survey result indicates that 45\% percent of houses are located within $350 \mathrm{~m}$ from nearer health center, $25 \%$ percent of houses are

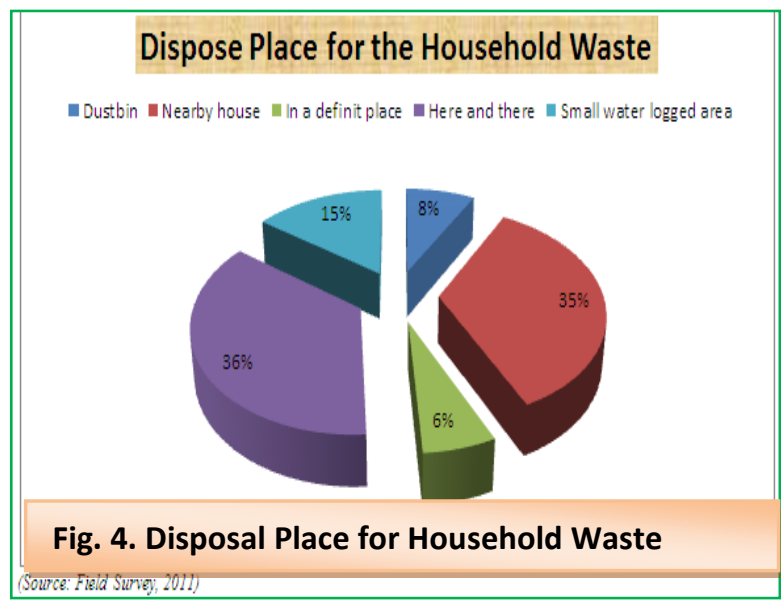

located within $250 \mathrm{~m}$ from the nearer health center, and other 30 percent houses are located more than $350 \mathrm{~m}$ from nearer health center.

Hazards and Disasters: The respondents were asked about the hazards or the disasters they face during living here. Most of them said that small fire hazards are common in this area but once there was a big fire hazards (3 times) happened and most of them didn't experience it as they were not here at that time. In case of disaster they said that if there was a strong wind circulation took place then roofs of the most houses will be broken down as they are not made properly and they have experienced such kind of disasters several times in a year. Strong wind (62\%), Water logging $(34 \%)$ are the main problems here and these gives birth to other problems.

Crime and Illegal Work: Many types of illegal work are occurred here. Theft and hijacking is main criminal works here $(36 \%)$. Other criminal works are like drug addiction (20\%), smuggling (25\%), terrorism (15\%) and others (4\%). Here, people were asked to select only one option which the respondent's thinks most dangerous and frequent in this slum. But the slum dwellers said that occasionally they have to pay money to the mastans and also the mastans take shelter in their slum for safety.

Migration Possibility: The natural feature of any slum is that most of the people are come from the village. In most case the people are migrated here due to increasing income and for employment. In case of migrating, the information is generally carried by relatives, friend, village people, and previous slum dwellers and so on. But most of the case the information is carried by the relatives and village 
people. But again some people want to move from here $(71 \%)$ because of many reasons.

Consequences of Informal Settlements on the Surroundings: Consequences of slum settlements have discussed with both the negative and positive effects and impact on the surrounding formal settlements. It was founded that they have enough knowledge about the consequences of the informal (slum) settlements. The main discussion is formal settler's opinions about the impact on commercial activities in the study area; assessments of the utilities services situation in the study area, types of facility provided by the informal settlers and the reasons for the growth of the informal settlements (opinion of the formal settler). Environmental and other services \& facilities situation of the informal settlements discusses about the environmental, utility services and other facilities consequences created by the informal settlers or for the existence of the informal settlements. This is the opinion of the formal settlers, because they are actually feeling the problems for the existence of the informal settlements.

Environmental conditions: The major environmental problems created by the informal settlers such as; the population overcrowding in the study area, noise pollution and waste pollution of the study area. It was the multiple response opinions (the responds gives more than one replies). $22 \%$ people have responded about the problem of the

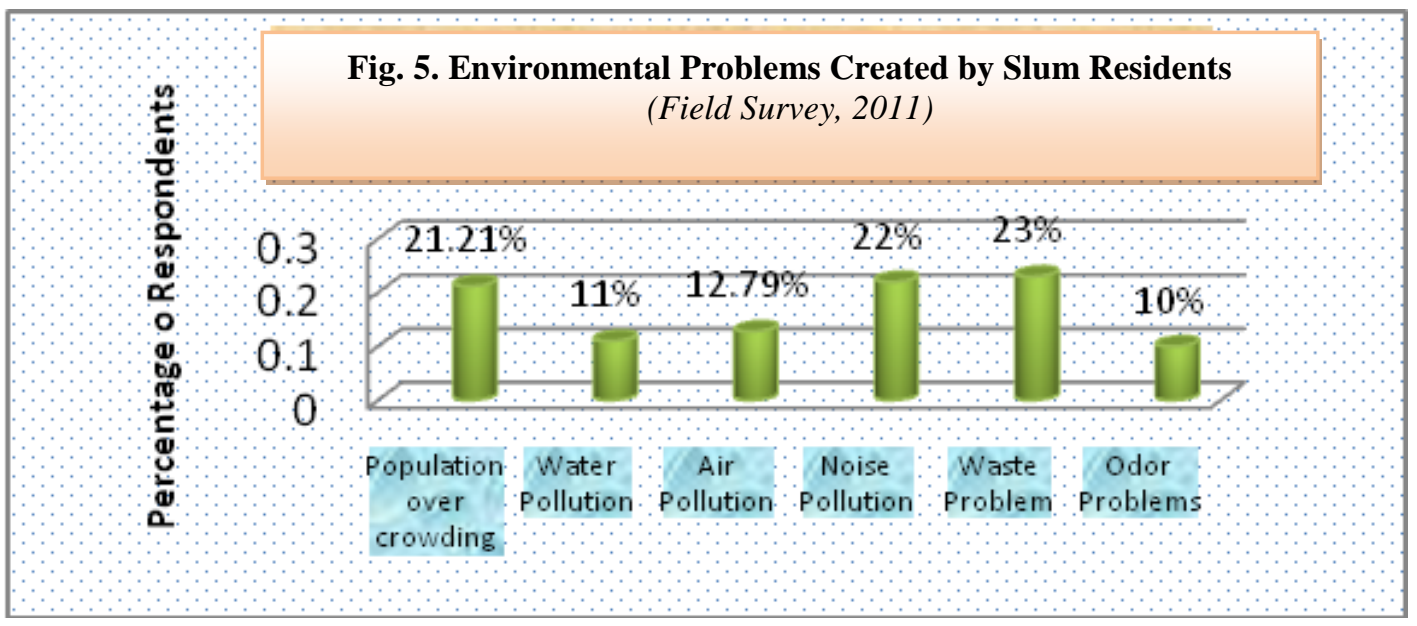

noise pollution. The lowest $10 \%$ respondents have responded about the problem of the odor problem of the study area. The reasons was that the waste water disposed by the informal settlers created the over loaded situation and the solid waste thronging in the drain creates the drainage congestion in the study area. Other two problems were, low voltage of electricity and the transportation problem.

Facilities provided by the slum settlers: Formal settlers are getting services from the slum people for different purposes and of course at a very low cost. It is very easy to get labor at a low cost from any slum area as their income is very low. The slum dwellers served the formal settler's in various ways. Such as working people for $\mathrm{HH}$ work (36\%), Low cost labor for small industry (17\%), Low cost labor available for any kind of work (28\%), more return comes from
Land (house rent) (10\%), and Others(9\%). Theopinions of the respective authorities against the objection of the formal settlers are endless. $20 \%$ respondents said that the respective authorities said "no comments" for their answer. The highest 40\% answer said that, "it is the concern of the land owner". In this case the land owner decided what types activities should be performed in his land. Other two answers has been found "illegally establish the settlements" and "Not possible to resettled them".

Views of formal settlers for the growth of informal settlements: The formal settlers also gives the same opinion like the informal settlers for the growth reasons of the informal settlements such as the employment problem in the village is the main problem for the growth of the informal settlements. $30 \%$ have given their views for this reason. $20 \%$ respondents said that number of poor people 
continuously increases in the city but the city's land is limited. $20 \%$ people responses for that the poor people have no low cost living places. And some people said that the poor people found the high income opportunities in the urban area and that why they migrate in the city.

\section{Discussion:}

Most of the third world countries especially the Bangladesh are facing the problem of housing. Housing problem is associated with various problems such as road network, water supply, drainage system etc. which are found in the study area are as follows:

Absence of adequate road network: Road is the basic service for housing development and also important to provide other services and facilities. Due to lack of organization and coordination most of the households are deprived of direct access to a motor able road. Nearly all of the roads of this study area are pucca. Only $33 \%$ of the household have an easy access to Jeep able roads and $67.5 \%$ of the households do not easy access to Jeep able roads from their residence. As a result road network in the study area remains to be a critical problem for residence.

Lack of proper drainage facilities: Due to rapid urbanization and increasing human settlements more and more retention areas are natural drainage are occupied by human habitation and for that urban area flood etc. So, drainage for urban development is very much necessary. In the study area, the drains are not only insufficient, but also improperly laid with faulty gradients, resulting in getting chocked with filthy water and refuse. Encroachment on the drainage path, inadequate drain sections, absence of outlets, indefinite drainage outlets, lack of proper maintenance of the existing drainage system and disposal of solid wastes into drains or drainage paths contribute to the backlog of drainage and water logging problems. The seasonal tidal effect and flat topography of land also cause drainage and water logging problems in the study area. About $86 \%$ percent of the households have no drainage facilities in and around their premises and 14 percent of the households have some sort of drainage facilities.

Absence of proper solid waste management system: Solid waste is the third pollutant after air and water. Due to lack of proper knowledge most of the household dispose their domestic waste in the nearby drain or nearby pond. As a result this waste impact on the physical environment and pollutes the pond water that people use this water for many purposes and create some diseases such as dysentery, diarrhea, cholera etc. Some of the households dispose their waste inside the house in a hole and create air pollution. One NGO provide some dustbin in the study area but those are very poor and more distance
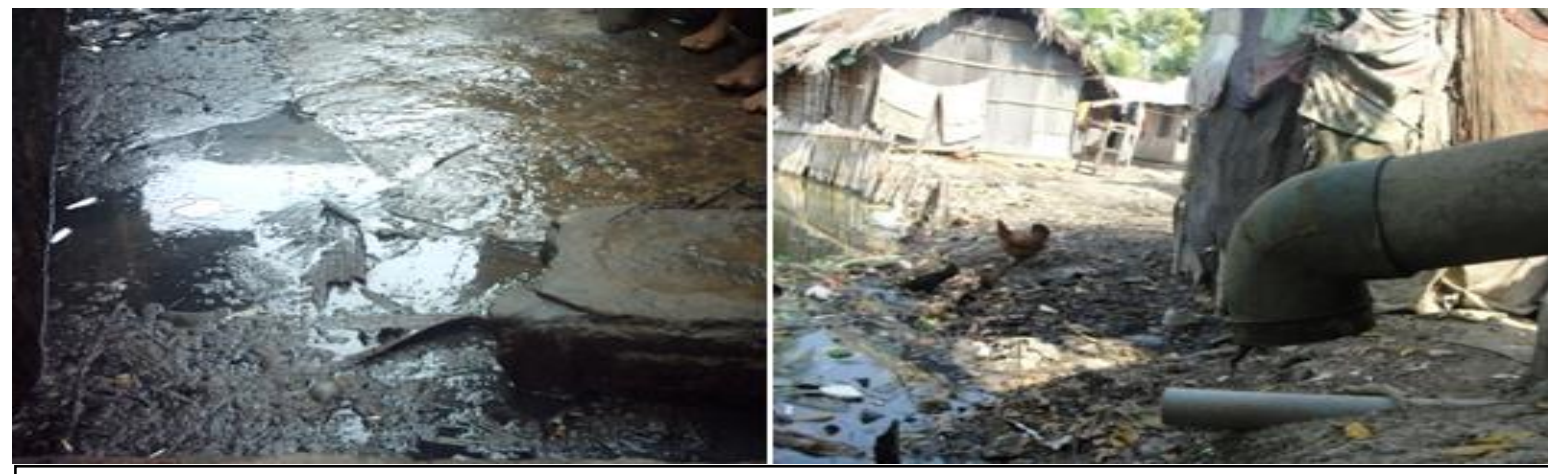

Fig. 6. Poor or no drainage system in the slum (Source: Field Survey, 2011)

faced different types of problem like water stagnation

Lack of health facilities: The unsanitary physical environment of the slum settlements affects the health of the dwellers. In the unhygienic environment prevailing in most low-income settlements, people complained mostly of stomach disorder, fever and measles. The doctors cited dysentery, diarrhea, and from home.

worms in stomach, malaria, typhoid and tuberculosis as the most common health problems. Infant and child mortality are high and have a crucial on acceptance of family planning, and also may be a major social indicator of the status of women and their different health care needs among various 
groups. The use of polluted water by a large number of inhabitants and unhygienic conditions prevailing in absence of proper system of lavatories and drainage are the major cause of most of the common diseases from which the slum dwellers suffered. In spite of poverty, a substantial number of dwellers do not go to the government or municipal dispensaries for treatment. The main reason reported is the long time spent in getting the treatment provided in these dispensaries. Settlement dwellers are of the view that free medicines given by government hospitals and dispensaries are of poor quality.

Absence of recreational facilities: The occupational life of the majority of slum dwellers is such that they find very little time for recreation. There is no time available for leisure in the daily routine of their life. Young children suffered from lack of recreation. In the study area there is a great lack or provision of parks and playgrounds. As a result people deprived from mental refreshment.

Shortage of shopping facilities: The slum dwellers earn their wages daily. Consequently they make small purchases for their daily necessities. All such needs of their shopping are provided by small shops within the settlements or by hawkers coming to this area. Weekly open-air bazaars are popular. In the study not satisfactory. No controlling effort has been found over the establishment of the informal settlements. The establishment and demolishment of the informal

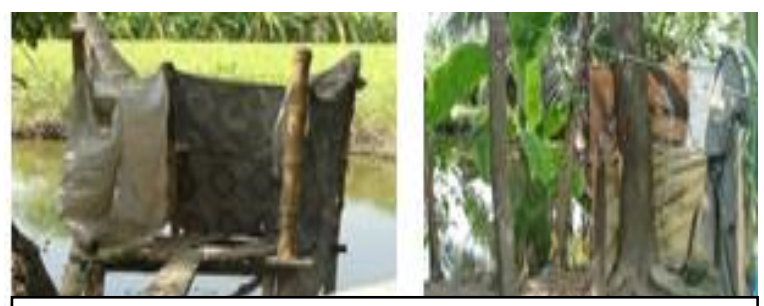

Fig. 7. Latrine shortage in the slum (Source: Field Survey, 2011)

settlements depends to its land owner. The study has found some informal settlements, which had demolished for the commercial uses of the land and some informal settlements were upgrading by it land owner for better rent from the land. It is the natural process of the growth and decline of the informal settlements in the city. So, from the total study it is clear that KCC has no developmental plan for the slum dwellers (especially khora slum) and at present they don't even think about it. There is no water supply from the KCC. Even they haven't spray anti- area there is a lack of shopping facilities. The existing two markets cannot meet the demand of the people. The quality of this market is not so good.

Shortage of latrines: Lack of toilets is the principal source of environmental degradation. The inadequate facilities for latrine and their overuse by too many persons in the absence of their regular cleaning had made most of them not only unserviceable but also unhygienic. The total absence of latrines and their insufficient forced the inhabitants to use the open space, wherever available for defecation. Young children defecated within the settlements, mostly on drains, adding to the sanitation problems of the area. In the study area, the latrine condition is very unhygienic which pollute the environment.

Conclusion: This study is an effort to define low income housing and low income group of the study area. Location choice is defined on the basis of mobility pattern and the adjustment with housing condition in terms of services and facilities and occupational point of view. In the Sonadanga bus stand of KCC there are both lower and middle \& high-income group people. The services and facilities for urban low income (slum) people housing development are mosquito spray in khora slum for last 10 years. Again there exists only 5 shallow tube wells, of which 3 are presently in use and the water quality was analyzed in our lab. One of the three tube wells shows a high salinity $(10 \mathrm{ppt})$ and the other two are moderate in salinity level. As the slum is situated near to the city bus station normally this place is noisy $(79 d B)$. KCC is the local authority for the delivering of municipal services to its dwellers. KCC provide services to all the people of their jurisdiction. The slum dwellers do not get pure and sufficient drinking water. Narrow and open drains with the poor water supply and dispose of wastes here and there cause different infection diseases in the slum children. A substandard housing area with poor water and sewerage facilities, or lack of access to income earning opportunities, can contribute to low family income, poor health and higher crime rate. Earning opportunities in the society can be improved by locating low-income housing areas near employment concentrations. In some ward of KCC there are predominantly lower and middle people. In this area there is no monetary or dissimilar incentive to 
revitalize urban low income people hosing development. Government policy and their convenient application can solve all this problems. Private sector involvement is also encouraged to abate housing problem KCC.

\section{References}

Anas, A. 1997. Urban Spatial structure (Transportation Centre, University of California at Berkeley USA).

Banglapedia, 2006. National encyclopedia of Bangladesh, Asiatic Society of Bangladesh, Dhaka.

Bangladesh Bureau of Statistics (BBS). 2008. Zilla Series, Khulna Division.Bangladesh Population Census 1991 \& 2001. Bangladesh.

Berensen, M. L. and Levine, D.M. 1992. Basic Business Statistics: Concepts and Application, $5^{\text {th }}$ edition. Pentin Hall, Inc. USA.

Centre for Urban Studies (CUS). 1990. The urban poor in Bangladesh, phase 1,volume 1 . University o Dhaka,, Dhaka.

Firoz, A. B. M. 2004. Urban Growth Dynamics of Khulna City: (A study on Ward No. 09, 20 and 24), Unpublished BURP Thesis, Khulna University, Khulna.

Islam. N.; and Ahsan. M. 1996. Urban Bangladesh: Geographical studies. Department of geography and environment, University of Dhaka.

Islam, N. 2001. Urbanization, Urban Settlements and Urban Development in Bangladesh. The University of Dhaka, Bangladesh.

Khulna Development Authority (KDA). 2000. Draft Structure plan, 2000, Aqua- Sheltech Consortium and KDA.

Murtaza, D. M. G. 2007. A Safe City is a Just CityThe Context of Khulna City. A seminar paper presented in world habitant day-2007, KDA, Khulna, Bangladesh.

Pellai. S. D. and Desai. A. R. 1990. Slum and Urbanization (Popular Prokashon Private Limited, Bombay).

Suri, D. P. 1994. The urban poor, their housing needs and government response, Har-Anand Publications, New Delhi. 